Тетяна Петрова

ORCID:orcid.org/0000-0002-9534-9891

DOI 10.31558/1815-3070.2021.42.9

УДК 82-95:811.161.2'374.26

\title{
СТАТУС РЕЦЕНЗЇ̈ НА ТЕРМІНОЛОГІЧНИЙ СЛОВНИК ЯК ТЕРМІНОГРАФІЧНА ЕКСПЕРТИЗА
}

У статті розглянуто жанри генеалогічно пов'язаних напрямів прикладної лінгвістики (лінгвістичної експертологї і термінографічної критики) - лінгвістичну експертизу й рецензію на термінологічний словник. Доведено, щьо ичі жанри мають низку подібних ознак. Запропоновано переглянути стереотипне розуміння змісту поняття «рецензія на термінологічний словник», а також використовувати термін «термінографічна експертиза» на позначення «публічного вироку» щуодо якості й цінності термінологічного словника, здійсненого на основі комплексного аналізу різнорівневих параметрів спеціального видання.

Ключові слова: дискурс, жанр, лінгвістична експертиза, рецензія на термінологічний словник, термінографічна експертиза, термінологічний словник, термінографічна критика.

Формулювання наукової проблеми та обгрунтування актуальности ії розгляду. Сучасна епоха $€$ «експертократичною»: розширюється парадигма експертного знання, з'являються нові види експертиз. «Експерти й експертизи нині проникли практично в усі сфери людської діяльності, і їх кількість та форми не можна точно підрахувати» (Волынкина 2018: 73).

Експертиза - «дослідження будь-якого питання обізнаною особою (експертом) 3 метою надання висновку (Завадський, Осовська, Юшкевич, 2006: 81). Аналіз метамови різних галузей знань засвідчує, що експертизу застосовують у діяльності органів державного управління, судочинстві, економіці, виробництва, торгівлі, техніці, мистецтві тощо. Відповідно, існують такі види експертизи: біологічна, бухгалтерська, грошових знаків, екологічна, криміналістична, медична, мистецтвознавча, технічна, товарознавча, сільськогосподарська, судова тощо. У кожній галузі активно використовують експертизу для оцінювання певних ii об'єктів, відповідно, вона досить затребувана й виконує особливу функцію, набуває специфічних ознак. Експертиза функціює в роз'ясненнях соціально-побутових ситуацій і наукових дослідженнях.

У лінгвістиці також актуалізована експертиза, зокрема 3-поміж основних напрямів прикладної лінгвістики, пов'язаної з практичним застосуванням, виокремлюють лінгвістичну експертизу. Це «спеціалізоване мовознавче дослідження текстових матеріалів та інших мовних об'єктів, а також невербальних засобів комунікації, які в поєднанні з вербальними генерують смисли у повідомленні» (Ажнюк 2016: 3).

У межах прикладної лінгвістики розвинулися лінгводидактика, термінознавство, перекладознавство, а також лексикографія. Термінографічна критика $є$ підрозділом термінографії, що входить до системи розділів лексикографії - напряму прикладної лінгвістики. Лінгвістична експертологія й термінографічна критика $\epsilon$ генеалогічно пов'язаними напрямами прикладної лінгвістики, утім спостерігається нерівність щодо кваліфікування статусу їх жанрів.

(C) Петрова Т., 2021 
Аналіз публікацій із досліджуваної проблеми. Вивчення різних аспектів лінгвістичної експертизи систематично здійснюють українські (Ажнюк 2012, 2016; Артикуца 2007; Богословська 2009; Космеда 2006, 2007) і закордонні (Баранов 2017; Волынкина 2018) науковці. Дослідженню специфіки рецензії на термінографічне джерело присвячені поодинокі праці (Петрова 2018, 2019а, 2019б). Порівняльно-зіставного аналізування ознак і статусу жанрів лінгвістичної експертизи й рецензії на термінологічний словник ще не здійснено, що й визначає актуальність цієї наукової студії.

Мета статті - переглянути стереотипне розуміння й статус рецензії на термінологічний словник; завдання - a) шляхом порівняльно-зіставного аналізу виявити схожі ознаки лінгвістичної експертизи й рецензії на термінологічний словник як репрезентантів оцінювального дискурсу та практик оцінювання спеціальних праць, б) запропонувати вживати термін, а відповідно, і дефініцію, що точно відобразить специфіку поняття на позначення комплексного аналізу спеціального словника.

Об'скт дослідження - жанрові форми лінгвістичної експертології й термінографічної критики (експертиза й рецензія), що $є$ генеалогічно пов'язаними напрямами прикладної лінгвістики та складниками оцінювального дискурсу; предмет - подібні ознаки й функції жанрів лінгвістичної експертизи й рецензії на термінологічний словник.

Фактичним матеріалом послугували спеціальні тексти (а) лінгвістичних експертиз і (б) рецензій на термінологічні словники.

У роботі застосовуємо низку методів, серед яких аксіологічний (для з'ясування ціннісних орієнтацій критиків словників, визначення критеріїв та алгоритму оцінювання структур спеціальних текстів) і метод порівняльно-зіставного аналізу (для виявлення спільних ознак лінгвістичної експертизи й рецензії на термінологічний словник через співвідношення особливостей лінгвістичного експертування й рецензування термінологічного словника).

Наукова новизна дослідження полягає у переосмисленні заниженого статусу рецензії на термінологічний словник як термінографічна експертиза та визнанні практики оцінювання спеціальних словників як термінографічне експертування.

Теоретичну цінність отриманих результатів становить доведення, що лінгвістична експертиза й рецензія на термінологічний словник $\epsilon$ рівнозначними за жанровими ознаками, призначенням і функцією, відповідно, рецензія - різнорівнева експертиза спеціальної праці. Практичну цінність одержаних результатів убачаємо в тому, що їх можна використати у процесі читання лекційних нормативних курсів та на практичних заняттях з термінографії, лінгвістики тексту, дискурслінгвістики, жанрології, лінгвоаксіології, у спецкурсах та спецсемінарах, присвячених проблемам сучасної української термінографії тощо.

Виклад основного матеріалу й обгрунтування результатів дослідження. Лінгвістична експертиза й рецензія на термінологічний словник - жанри оцінювального дискурсу. Поняття лінгвістичної експертизи є нестійким. Науковці пропонують його власні дефініції. Це засвідчує й неуніфіковане його викори- 
стання в науковій літературі термінів-варіантів і термінів-синонімів, як-от: лінгвістична експертиза, лінгвістичне діагностування, лінгвоекспертне дослідження тощо. У науковій літературі по-різному інтерпретують зміст поняття лінгвістична експертиза, наприклад: «спосіб дослідження тексту з метою надання кваліфікованої експертної оцінки різних параметрів тексту, мовних засобів різного рівня (графічних, фонетичних, граматичних, стилістичних тощо), їх відбору і використання, відповідності певним нормам і критеріям» (Артикуца 2007: 48). Таке пояснення аналізованого поняття особливо привертає увагу авторки цієї статті, оскільки рецензія на термінологічний словник теж $є$ «однією з найважливіших форм сучасної наукової експертизи спеціальних словників» та «найважливішим інструментом відбирання для критичного експертизування термінографічних праць, насамперед їхніх структурних частин та лексикографічних параметрів» (Петрова 2019а: 134). Між тим Б. Степанов книжкові рецензії також розуміє як «один з найбільш важливих інструментів наукової експертизи», «найважливішим інструментом відбору, критичної оцінки й експертизи значущих для найрізноманітніших культурних інститутів», «засобом академічної експертизи» (Степанов 2016: 82 -83) і вважає, що вони «володіють певною специфікою порівняно з іншими формами експертизи i, зокрема, іншими практиками рецензування» (Степанов 2016: 84). Отже, названі науковці розуміють рецензію на термінологічний словник і на книги як експертизу.

Разом $з$ тим лінгвістичну експертизу визначають як «особливий жанр тексту, в основі якого лежить наукове дослідження» (Баранов 2017: 20), а експертизу - як мовленнєвий жанр наукового стилю (Загнітко 2012: 282) або оцінювальний жанр (Волынкина 2018: 73) тощо. Сучасна експертиза може реалізовуватися в різних формах, зокрема короткими репліками спеціалістів, повноцінними письмовими експертними висновками й навіть багатосерійними розслідуваннями (Волынкина 2018: 73).

Утім погіршення якості лінгвістичних знань, а також прагматичні фактори, «спричиняють зниження наукового рівня експертних досліджень, перетворюючи їх на тексти жанру “чого бажаєте”», причину такого стану вбачають у «згубній тенденції розвитку лінгвістичної експертизи, яка в найближчій перспективі безсумнівно призведе до зникнення обговорюваного напряму як суспільно корисної і затребуваної діяльності» (Баранов 2017: 19). Думки фахівців збігаються щодо того, що лінгвістична експертиза в Україні «як самостійний вид експертизи ще не сформувався, окремі питання теоретичних основ потребують подальшої наукової роботи» (Богословська 2009: 2), «потребує теоретичного опису ії̈ статус, метамова, методика, принципи реалізації і под., необхідні й напрацювання щодо зразків різних типів ЛЕ, що, очевидно, можна вважати пріоритетним завданням сучасної прикладної лінгвістики» (Космеда 2006).

Рецензія на термінологічний словник - базовий жанр термінографічної критики, а також оцінювальний жанр критичного субдискурсу. Аналізовані експертиза й рецензія, як бачимо, мають спільне: вони є жанровими репрезентантами оцінювального дискурсу. За авторськими спостереженнями, жанр рецензії на тер- 
мінологічний словник теж потребує неабиякої підтримки, а головно перегляду розуміння термінографічної критики як експертизи спеціальних видань.

Терміни рецензія, рецензент, рецензування також функціюють у судовій експертизі, де рецензування розуміють як «один з інструментів забезпечення справедливого судочинства», необхідність якого виникає, якщо висновки експертів судової справи є неякісними та помилковими. Автор такої рецензії «оцінює висновок експерта з точки зору обгрунтованості, повноти дослідження, відповідності вимогам нормативно-правових документів, що регулюють проведення судових експертиз» (Круть 2017). У цій ситуації рецензентові та його рецензії відводять спеціальну й найважливішу роль - роль «останнього слова». Це вказує на розуміння ії статусу як вищого, ніж в експертизи, що відмінно від стереотипного iii трактування у прикладній лінгвістиці, зокрема в термінографічній критиці.

Лінгвістичне експертування й рецензування термінологічного словника як практики оцінювання спеціальних текстів (докладно див. про це: Петрова 2020). Найпоширенішими об'єктами лінгвістичної експертизи можуть бути, як відомо, усні та писемні тексти як складники відповідного дискурсу, зокрема різножанрові тексти різного обсягу: агітаційна листівка, гасло, законопроєкти, нормативно-правові акти, конфліктні й рекламні тексти, публіцистичний текст, стаття, усний виступ, ділові папери тощо. Об'єкт аналізу термінографічної критики - це термінологічні словники як особливий вид наукових текстів.

Лінгвістичне експертування й рецензування термінографічного видання це комплексне оцінювання спеціальних видів текстів (відповідно законопроєктів, договорів та ін.; фахових словників). «Сучасна практика проведення лінгвістичних експертиз є здебільшого стихійною, індивідуально-суб'єктивною» (Ажнюк 2012: 49). Певною мірою це характерно й для рецензування термінологічних словників.

Для проведення лінгвістичної експертизи застосовують різні лінгвістичні й екстралінгвістичні параметри. Зокрема, унаслідок лінгвістичного моніторингу текстів законодавчих документів виявлено низку недоліків: «термінологічна невпорядкованість і неузгодженість; дублетність, синонімія і варіативність термінологічних одиниць ...; “семантична дифузність” та неоднозначність правової норми; ... двозначність тексту; алогізми; мовленнєва недостатність; невмотивована тавтологічність; лексична надлишковість; зміщення смислових меж; стильова невідповідність; невмотивована ускладненість синтаксичних конструкцій; порушення родо-видових зв'язків між поняттями, форм узгодження й керування; уживання запозичень замість наявного українського терміна; невиправдане калькування; розбіжності у формах однини і множини, відмінкових форм; значна кількість росіянізмів тощо» (Артикуца 2007: 48). В аспекті викладеного Т. Космеда зазначає: «Доцільно було б затвердити правила єдиного використання термінів, інших елементів словесно-документальної форми нормативно-правових актів. Тим самим були б закладені основи соціально визнаної системи підготовки законодавчих текстів» (Космеда 2007: 111).

Під час аналізування параметрів термінологічних словників критики найчастіше викладають такі зауваження до структурних параметрів, наприклад, пере- 
кладних дефінітивних словників: 'реєстр словника' - 1) відсутність багатьох одиниць, що є складниками описуваної галузі / зайвість навмисно залучених термінів, які не належать до описуваної терміносистеми; 2) необхідність замінити реєстрові одиниці іншими спеціальними назвами; 'зона перекладу' - неправильність перекладу, поширеність кальок; 'дефініція' - неточність дефініювання понять тощо (див. Петрова 2019б: 100-102). У текстах, що є об’єктом лінгвістичних експертиз, і в термінографічних виданнях, як бачимо, засвідчено «пекучу» проблему - нормалізування термінів у фахових словниках з урахуванням змін у мові та поглядах на норму в термінології.

Припускаємо, що виявлені недоліки в законодавчих текстах спричинені головно недосконалістю спеціальних джерел, відповідно, можна встановити такий напрям зв'язку між досліджуваними об'єктами, як-от: словник використовується під час написання законопроєктів чи експертних висновків, вирішення проблемних питань як довідкове видання, як інструмент і джерело роз'яснення спірної ситуації, а також як унікальний об'єкт комплексного критичного аналізу. Рецензування фахових словників і лінгвістичне експертування розглядаємо в окресленому аспекті як рівнозначні якісні практики оцінювання спеціальних праць, тобто практики діагностування, основою яких є сукупність необхідних знань, досвід, що здобуті впродовж певного часу й виявилися ефективними під час розв'язання подібних проблем.

Помітним $є$ і спільний принцип, покладений в основу процесів експертування й рецензування, - вироблення рекомендацій методологійного характеру щодо встановлених порушень в оцінюваних роботах тощо. Зокрема, з урахуванням усіх виявлених у законодавчих текстах помилок і недоліків «розробляються методичні рекомендації щодо мовностилістичного оформлення проектів нормативно-правових актів, правила побудови законодавчих дефініцій, практичні поради щодо дотримання загальних вимог до тексту закону та національних і міжнародних термінологічних стандартів, пропонується певний алгоритм дій нормопроектувальника для розв'язання термінологічних проблем» (Артикуца 2007: 49). Методологійним стрижнем лінгвістичної експертизи вважають «використання нормативного (прескриптивного) підходу до аналізу різнорівневих мовних явищ» (Ажнюк 2012: 50).

Конструктивні зауваження рецензентів фахових словників окреслюють перспективу щодо покращення їхньої якості. Відповідно, «рецензії на термінологічні словники мають важливе теоретико-практичне значення: систематизування виявлених критичних оцінок і недоліків репрезентування структурних параметрів видань такого типу сприятиме вдосконаленню теоретико-методологічних основ метатермінографії задля практичного якісного реалізування спеціальних праць» (Петрова 2019б: 103). Результати досліджень означених текстів можуть бути подані у формі рекомендацій чи консультацій.

Спільним також для лінгвістичного експертування й рецензування словників термінів $\epsilon$ чинник застосування поетапного алгоритму комплексного оцінювання якості праць (Артикуца 2007: 49; Петрова 2018: 212). Так, на першому етапі лінгвістичного експертування текстів законопроєктів здійснюють дослідження 
«термінологічної сумісності аналізованого законопроекту з іншими законами, ..., спостереження над дотриманням чіткої системності, логічності, ієрархічності поняттєво-термінологічного апарату, ..., визначення правильності й внутрішньої узгодженості дефініцій законодавчих термінів» (Артикуца 2007: 49). Під час рецензування фахового словника на першому етапі необхідно (1) проаналізувати елементи його мегаструктури (передмову, правила користування, перелік скорочень, корпус словника, список джерел, покажчик) на відповідність принципам їхньої побудови, (2) установити відповідність типу словника, заявленому в тексті передмови, реальному, (3) з'ясувати відповідність призначення словника, зафіксованому у передмові (докладно див. про це: Петрова 2018: 212).

Викладене вище засвідчує застосування спільних для експертування й рецензування наукових методів оцінки спеціальних текстів - порівняльного методу, дефінітивного аналізу, структурно-семантичного й логіко-поняттєвого аналізу тощо. Помітною $є$ «дзеркальність» основних принципів методологійної основи поетапних алгоритмів аналізування названих праць.

Спеціальні тексти (напр., законопроєкти, договори та ін.; термінологічні словники), що стають об'єктами експертування й рецензування, потребують діагностування їхньої побудови з метою встановлення відповідності кожної структурної частини вимогам до робіт такого типу. Текст договору є цілісною одиницею мовлення «з усталеною макроструктурою (композицією) й уніфікованим лексико-граматичним оформленням одиниць, які належать до нижчих структурних рівнів - надфразових єдностей і окремих речень» (Ажнюк 2012: 53). Композицію рецензії на термінологічний словник розглядаємо як ієрархічну мегаструктуру, а її складники Заголовок, Встуn, Основну частину й Висновки визначаємо як співкомпоненти нижчого рівня ієрархії, що створюють іiї макроструктуру, субкомпоненти компонентів формують ії мікроструктуру. Композицію лінгвістичної експертизи й рецензії на словник термінів, що є вторинними текстами, зумовлюють особливості побудови первинних текстів, тобто відповідно договору, законопроєкту тощо й термінологічного словника.

Рецензія на термінологічний словник - термінографічна експертиза. Панування аксіологічних підходів щодо оцінювання спеціальних форм знань стимулює уніфікування поняттєво-термінологічного апарату термінографічної критики, зокрема обгрунтування змісту понять, що репрезентують засади експертування термінографічної праці.

Чи можна інтерпретувати рецензування термінологічних словників як їх експертування? У сучасному мовознавстві існують наукові праці, присвячені вивченню лексикографічної експертизи як одного з критеріїв ідентифікації авторських новотворів (Максимчук 2012: 55). Г. Вокальчук і вслід за ним В. Максимчук розуміють лексикографічну експертизу як «скурпульозне опрацювання дослідником максимальної кількості різножанрових словників задля уточнення реєстру власне авторських інновацій〉 (Вокальчук 2011; Максимчук 2012: 56).

Визначаючи основні завдання історіографії українського термінознавства, В. Іващенко вказує на необхідність проаналізувати «історію організації термінологічної діяльності, зокрема в галузі упорядкування термінологій, стандартизації, термінологічної експертизи ... 3 моменту виникнення й дотепер» (Іващен- 
ко 2013: 6). В українському термінознавстві об'єктом експертування стали, як видається, терміни (термінологія), термінологічні стандарти тощо.

В аспекті досліджуваної проблеми пропонуємо використовувати в науковому обігу одиницю термінографічна експертиза (експертиза термінологічного словника, експертиза термінографічного видання). Зміст терміна лінгвістична експертиза, як підтверджує мовна практика, на відміну від суті терміна рещензї̈ на термінологічний словник, традиційно сприймають як дослідження вищого рівня кваліфікації. Проведений порівняльно-зіставний аналіз засвідчив рівнозначність їхніх статусів за жанровими особливостями, призначенням і функцією. Усе це зумовлює нагальну необхідність перегляду розуміння значущості оцінки термінографічного видання й визнання ії як різнорівневої експертизи такої праці. Отже, термінографічне експертування - це оцінювання якості репрезентації параметрів різних рівнів структури термінографічного джерела 3 урахуванням положень алгоритму поетапного його аналізу. Термінографічна експертиза це (1) одна з особливих форм сучасного наукового аналізування спеціальних словників; (2) найважливіший інструмент критичного оцінювання термінографічних праць, насамперед їхніх лексикографічних параметрів різнорівневих структурних частин; (3) базовий жанр термінографічної критики, а також оцінювальний жанр критичного субдискурсу; (4) вторинний текст, у якому викладають результати розгляду якості репрезентації параметрів первинного тексту - фахового словника як особливого виду тексту.

Викладене дає змогу зробити декілька висновків. Лінгвістична експертиза й рецензія на термінологічний словник як жанри генеалогічно пов'язаних напрямів прикладної лінгвістики й водночас репрезентанти оцінювального дискурсу мають схожі / спільні (1) ознаки - а) комплексність дослідження спеціальних видів праць, б) вторинність текстів, композиція яких залежить від побудови, змісту первинних текстів; (2) об'єкт аналізу - спеціальні тексти (нормативно-правові документи; термінологічні словники); (3) принции, що покладений в основу експертування, - вироблення рекомендацій методологійного характеру щодо виявлених у документах недоліків; (4) наукові методи оиінювання текстів - порівняльний, дефінітивного аналізу, логіко-поняттєвого аналізу тощо; (5) поетапний алгоритм комплексного оцінювання якості праџь тощо. Усе це слугує підставою для спростування загальноприйнятої інтерпретації суті терміна рецензія на термінологічний словник, визнання й справедливого використання в науковому обігу терміноодиниць термінографічна експертиза ('своєрідний «публічний вирок» щодо якості й цінності фахового словника, виконаного на основі комплексного аналізу його різнорівневих параметрів'), а також термінографічне експертування ('a / усебічна оцінка якості й значущості термінографічного видання; б / спеціалізований напрям критично-оцінювального дослідження наукових праць довідкового характеру, що відіграє принципову й важливу роль у формуванні методології метатермінографії).

Умотивоване переосмислення змісту базових термінопонять оцінювального дискурсу й доречне оперування ними стимулюватимуть зміцнення статусу рецензії на фаховий словник як термінографічної експертизи. Це сприятиме її визнан- 
ню як спеціалізованої лабораторії термінографічної критики, підкреслить авторитет експерта джерела, спонукатиме фахівців-критиків до активної діяльності, а відповідно, позитивно вплине на розвиток спеціальної критики, а головно підвищить якість української термінографічної продукції.

Перспективи дослідження вбачаємо в необхідності детального вивчення особливостей рецензії в судовій експертизі.

\section{Література}

1. Ажнюк, Леся В. «Лінгвістична експертиза: статус і методологічні презумпції» [В:] Мовознавство 3, 2012: 47-64.

[Azhniuk, Lesia V. «Linhvistychna ekspertyza: status i metodolohichni prezumptsii» [V:] Movoznavstvo 3, 2012: 47-64.]

2. Ажнюк, Леся В. «Типологія об'єктів лінгвістичної експертизи і методика їх дослідження» [B:] Мовознавство 3, 2016: 3-18.

[Azhniuk, Lesia V. «Typolohiia obiektiv linhvistychnoi ekspertyzy i metodyka yikh doslidzhennia» [V:] Movoznavstvo 3, 2016: 3-18.]

3. Артикуца, Наталія В. «Законодавчий текст як предмет лінгвістичної експертизи». [В:] В. І. Терентьєв, О. В. Козаченко (ред.). Визначальні тенденщіі генезису державності $i$ права. Миколаїв: Іліон, 2007, 48-56.

[Artykutsa, Nataliia V. «Zakonodavchyi tekst yak predmet linhvistychnoi ekspertyzy». [V:] V. I. Terentiev, O. V. Kozachenko (red.). Vyznachalni tendentsii henezysu derzhavnosti $i$ prava. Mykolaiv: Ilion, 2007, 48-56.]

4. Баранов, Анатолий Н. (2017). «Лингвистика в лингвистической экспертизе (метод и истина)» [В:] Вестник Волгоградского государственного университета. Серия 2. Языкознание 16 (2), 2017: 18-27.

[Baranov, Anatoliy N. (2017). «Lingvistika v lingvisticheskoy ekspertize (metod i istina)» [V:] Vestnik Volgogradskogo gosudarstvennogo universiteta. Seriya 2. Yazykoznaniye 16 (2), 2017: 18-27].

5. Богословська, Марина О. Судова лінгвістична експертиза: процесуальні та кримінальні аспекти : автореф. дис. ... канд. юрид. наук : 12.00.09. Київ, 2009. 19 с.

[Bohoslovska, Maryna O. Sudova linhvistychna ekspertyza: protsesualni ta kryminalni aspekty : avtoref. dys. ... kand. yuryd. nauk : 12.00.09. Kyiv, 2009. 19 s.]

6. Вокальчук, Галина М. «Українська індивідуально-авторська неографія: стан і перспективи» [В:] Вісник Дніпропетровського університету. Серія «Мовознавство» 17 (1), 2011. URL: http://movoznavstvo.com.ua/download/pdf/2011_1/article/5.pdf (25.12.2020).

[Vokalchuk, Halyna M. «Ukrainska indyvidualno-avtorska neohrafiia: stan i perspektyvy» [V:] Visnyk Dnipropetrovskoho universytetu. Seriia «Movoznavstvo» 17 (1), 2011. URL: http://movoznavstvo.com.ua/download/pdf/2011_1/article/5.pdf (25.12.2020).]

7. Волынкина, Светлана В. «Рассвет экспертизы как отражение изменений в жизни современного российского общества» [В:] Филологические науки. Вопросы теории и практики 10 (88/1), 2018: 72-80.

[Volynkina, Svetlana V. «Rassvet ekspertizy kak otrazheniye izmeneniy v zhizni sovre-mennogo rossiyskogo obshchestva» [V:] Filologicheskiye nauki. Voprosy teorii i praktiki 10 (88/1), 2018: 72-80.]

8. Завадський, Йосип С., Осовська, Галина В., Юшкевич, Олена О. Економічний словник. Київ: Кондор, 2006.

[Zavadskyi, Yosyp S., Osovska, Halyna V., Yushkevych, Olena O. Ekonomichnyi slovnyk. Kyiv: Kondor, 2006.] 
9. Загнітко, Анатолій. Словник сучасної лінгвістики: поняття і терміни: у 4 т. Донецьк: ДонНУ, 2012.

[Zahnitko, Anatolii. Slovnyk suchasnoi linhvistyky: poniattia i terminy: u 4 t. Donetsk: DonNU, 2012.]

10. Іващенко, Вікторія Л. «Історіографія термінознавства: метамова і структурні підрозділи» [B:] Термінологічний вісник 2 (1), 2013: 5-20.

[Ivashchenko, Viktoriia L. «Istoriohrafiia terminoznavstva: metamova i strukturni pidrozdily» [V:] Terminolohichnyi visnyk 2 (1), 2013: 5-20.]

11. Космеда, Тетяна А. «“Лінгвістична експертиза” однієї лінгвістичної експертизи (до питання про правомірність використання терміна)», 2006. URL: http://res.in.ua/lingvistichnaekspertiza-odniyeyi-iniciativnoyi-lingvistichnoy.html (12.01.2021).

[Kosmeda, Tetiana A. «"Linhvistychna ekspertyza” odniiei linhvistychnoi ekspertyzy (do pytannia pro pravomirnist vykorystannia termina)», 2006. URL: http://res.in.ua/lingvistichnaekspertiza-odniyeyi-iniciativnoyi-lingvistichnoy.html (12.01.2021).]

12. Космеда, Тетяна А. «Термінологія і мова закону: проблемні питання» [В:] Украӥнська термінологія і сучасність VII, 2007: 107-111.

[Kosmeda, Tetiana A. «Terminolohiia i mova zakonu: problemni pytannia» [V:] Ukrainska terminolohiia i suchasnist' VII, 2007: 107-111.]

13. Круть, О. «Рецензування висновків експертів допоможе уникнути помилок, що позначаються на долі конкретної людини» [В:] Закон і бізнес. Дослідження з порушеннями 37, (1335) 30.09-06.10.2017. URL: https://sk.ks.court.gov.ua/sud2119/pres-centr/news/388913/ (21.01.2020).

[Krut', O. «Retsenzuvannia vysnovkiv ekspertiv dopomozhe unyknuty pomylok, shcho poznachaiutsia na doli konkretnoi liudyny» [V:] Zakon i biznes. Doslidzhennia z porushenniamy 37, (1335) 30.09-06.10.2017. URL: https://sk.ks.court.gov.ua/sud2119/pres-centr/news/388913/ (21.01.2020).]

14. Максимчук, Віталій В. «Лексикографічна експертиза як один із критеріїв ідентифікації авторських новотворів» [В:] Наукові записки. Серія «Філологічна» 31, 2012: 55-60.

[Maksymchuk, Vitalii V. «Leksykohrafichna ekspertyza yak odyn iz kryteriiv identyfikatsii avtorskykh novotvoriv» [V:] Naukovi zapysky. Seriia «Filolohichna» 31, 2012: 55-60.]

15. Петрова, Тетяна. «Рецензія на термінологічний словник як жанр критичного субдискурсу» [B:] Наукові праці Кам'янець-Подільського національного університету імені Івана Огієнка: Філологічні науки 50, 2019а: 133-139.

[Petrova, Tetiana. «Retsenziia na terminolohichnyi slovnyk yak zhanr krytychnoho subdyskursu» [V:] Naukovi pratsi Kamianets-Podilskoho natsionalnoho universytetu imeni Ivana Ohiyenka: Filolohichni nauky 50, 2019: 133-139.]

16. Петрова, Тетяна О. «Теоретико-практичне значення рецензій на українські термінологічні словники кінця XX ст. - поч. XXI ст.» [В:] Проблеми загального і слов'янського мовознавства 3, 2019б: 9-106.

[Petrova, Tetiana O. «Teoretyko-praktychne znachennia retsenzii na ukrainski terminolohi-chni slovnyky kintsia KhKh st. - poch. KhKhI st.» [V:] Problemy zahalnoho i slovianskoho movoznavstva 3, 2019: 96-106.]

17. Петрова, Тетяна О. «Українська термінографічна критика: від витоків до сучасності» [В:] Науковий вісник Наи. ун-ту біоресурсів і природокористування України. Серія: Філологічні науки 292, 2018: 208-217.

[Petrova, Tetiana O. «Ukrainska terminohrafichna krytyka: vid vytokiv do suchasnosti» [V:] Naukovyi visnyk Nats. un-tu bioresursiv i pryrodokorystuvannia Ukrainy. Seriia: Filolohichni nauky 292, 2018: 208-217.]

18. Петрова, Татьяна. «Современные практики оценки специальных текстов: лингвистическая и терминографическая экспертизы» [В:] Jezikoslovni zapiski 26 (2), 2020: 155-171. 
[Petrova. Tatiana. «Sovremennyye praktiki otsenki spetsialnykh tekstov: lingvistiche-skaya i terminograficheskaya ekspertizy» [V:] Jezikoslovni zapiski 26 (2), 2020: 155-171.]

19. Степанов, Борис. «“Кризис жанра": книжные рецензии в перспективе исследований научной коммуникации» [В:] Laboratorium 8 (1), 2016: 82-106.

[Stepanov, Boris. «"Krizis zhanra”: knizhnyye retsenzii v perspektive issledovaniy nauchnoy kommunikatsii» [V:] Laboratorium 8 (1), 2016: 82-106.]

20. Шевченко, Лариса I., Дергач, Дмитро В., Сизонов, Дмитро Ю. Медіалінгвістика: словник термінів і понять. Вид. 2-ге, випр. і доп. Київ: ВПЦ «Київський університет», 2014.

[Shevchenko, Larysa I., Derhach, Dmytro V., Syzonov, Dmytro Yu. Medialinhvistyka: slovnyk terminiv i poniat. Vyd. 2-he, vypr. i dop. Kyiv: VPTs «Kyivskyi universytet», 2014.]

\section{STATUS OF REVIEW OF A TERMINOLOGICAL DICTIONARY AS TERMINO- GRAPHIC EXAMINATION \\ Tetiana Petrova}

Department of Language Disciplines, Kharkiv National Agrarian University named after V. V. Dokuchayev, Kharkiv, Ukraine.

Abstract

Background: Linguistic expertology and terminographic criticism are the areas of applied linguistics, but there is inequality as to qualification of their genres status - linguistic examination and review of a terminological dictionary. There is a need for the comparative and contrastive analysis of features and status of genres of linguistic examination and review of a terminological dictionary.

Purpose: The purpose of this article is to reconsider stereotypical understanding and status of review of a terminological dictionary.

Results: Linguistic examination and review of a terminological dictionary are (a) the genres of genealogically related areas of applied linguistics, as well as (b) representatives of evaluative discourse. By the comparative and contrastive analysis it has been established that linguistic examination and review of a terminological dictionary have similar features - a) research complexity of special work types, b) secondaryness of texts, composition of which depends on construction, content of primary texts. The objects of examination and review are special texts - normative legal documents and terminological dictionaries. In the process of their analysis, the common (1) principle of making methodological recommendations on shortcomings identified in documents; (2) scientific methods of text evaluation - comparative, definitive analysis, logical and conceptual analysis, etc.; as well as (3) a step-by-step algorithm for a comprehensive study of work quality, etc. are applied.

Discussion: Linguistic examination and review of a terminological dictionary are equivalent qualitative practices for evaluating special works, i. e. diagnostic practices, which are based on necessary knowledge, experience gained over time and proved effective in solving such problems. Terminographic examination is 'a kind of «public verdict» on quality and value of a professional dictionary, made on the basis of a comprehensive analysis of its various level parameters'; terminographic expertise is 'a) comprehensive evaluation of quality and significance of a terminographic publication; b) specialized direction of critical and evaluation research of scientific works of reference nature, which plays a fundamental and important role in formation of metaterminography methodology'.

Motivated rethinking of the basic terms content of evaluative discourse and appropriate operation of them will stimulate strengthening of professional dictionary review status as terminographic examination and recognition as a specialized laboratory of terminographic criticism.

The prospects of the research are seen in a detailed study of the review features in the forensic examination.

Keywords: discourse, genre, linguistic examination, review of terminological dictionary, terminographic examination, terminological dictionary, terminographic criticism. 


\section{Vitae}

Tetiana Petrova is PhD in Philology, Docent, Associate Professor at the Department of Language Disciplines, Kharkiv National Agrarian University named after V. V. Dokuchayev. Her areas of research interests include Ukrainian terminology, terminography, terminographic criticism.

Correspondence: t.petrova.science@gmail.com

Надійшла до редакції 28 серпня 2021 року Рекомендована до друку 08 жовтня 2021 року 